\title{
Alfred Vulpian and Jean-Martin Charcot in Each Other's Shadow? From Castor and Pollux at La Salpêtrière to Neurology Forever
}

\author{
Julien Bogousslavsky ${ }^{\mathrm{a}}$ Olivier Walusinski ${ }^{\mathrm{b}}$ Thierry Moulin ${ }^{\mathrm{c}}$ \\ ${ }^{a}$ Center for Brain and Nervous System Disorders, and Neurology and Neurorehabilitation Services, \\ Genolier Swiss Medical Network, Clinique Valmont, Glion/Montreux, Switzerland; 'b Private practice, Brou, \\ and ' University Department of Neurology, Hôpital Jean-Minjoz, Besançon, France
}

\section{Key Words}

Alfred Vulpian $\cdot$ Jean-Martin Charcot $\cdot$ Friends

\begin{abstract}
While Alfred Vulpian (1826-1887) is not completely forgotten, he cannot match the uninterrupted celebrity which Jean-Martin Charcot (1825-1893) still enjoys today. After becoming interne (residents) at the same institute in 1848 , both were involved in shaping the cradle of what would become modern neurology. Both started work as chiefs at a La Salpêtrière service on January 1, 1862, making common rounds and studies, with several common publications. While their friendship remained 'for life', as stated by Charcot at Vulpian's funeral, their career paths differed. Vulpian progressed quicker and higher, being appointed full professor and elected at the Académie Nationale de Médecine and the Académie des Sciences several years before Charcot, as well as becoming dean of the Paris Faculty of Medicine. These positions also enabled him to support his friend Charcot in getting appointed full clinical professor and becoming the first holder of the chair of Clinique des Maladies du Système Nerveux in 1882. Before studying medicine, Vulpian had worked in physiology with Pierre Flourens, and his career always remained balanced between physiology and neurolo-
\end{abstract}

gy, with remarkable papers. He introduced Charcot to optic microscopy during their La Salpêtrière years, indirectly helping him to become his successor to the chair of pathological anatomy in 1872. While Vulpian succeeded so well in local medical affairs, Charcot spent his time building up a huge clinical service and a teaching 'school' at La Salpêtrière, which he never left for over 31 years until his death. This 'school' progressively became synonymous with clinical neurology itself and perpetuated the master's memory for decades. Vulpian never had such support, although Jules Déjerine was his pupil and Joseph Babinski was his interne before becoming Charcot's chef de clinique (chief of staff) in 1885. This unusual switch in Parisian medicine contributed to Charcot's unaltered celebrity over more than a century, while Vulpian was progressively relegated to the studies of historians. However, Vulpian and Charcot remain inseparable in the memory of a lifelong friendship which gave birth to neurology.

Copyright $\odot 2011$ S. Karger AG, Basel

Jean-Martin Charcot (1825-1893; fig. 1) is considered the father of modern neurology [1] as well as the main instigator of the evolution of alienism into modern psychiatry [2]. His lifelong best friend in the field of medicine

\section{KARGER}

Fax +4161306 1234 E-Mail karger@karger.ch www.karger.com (c) 2011 S. Karger AG, Basel $0014-3022 / 11 / 0654-0215 \$ 38.00 / 0$

Accessible online at: www.karger.com/ene
J. Bogousslavsky, MD

Clinique Valmont

CH-1823 Glion/Montreux (Switzerland)

Tel. +41219623700

E-Mail jbogousslavsky@cliniquevalmont.ch 


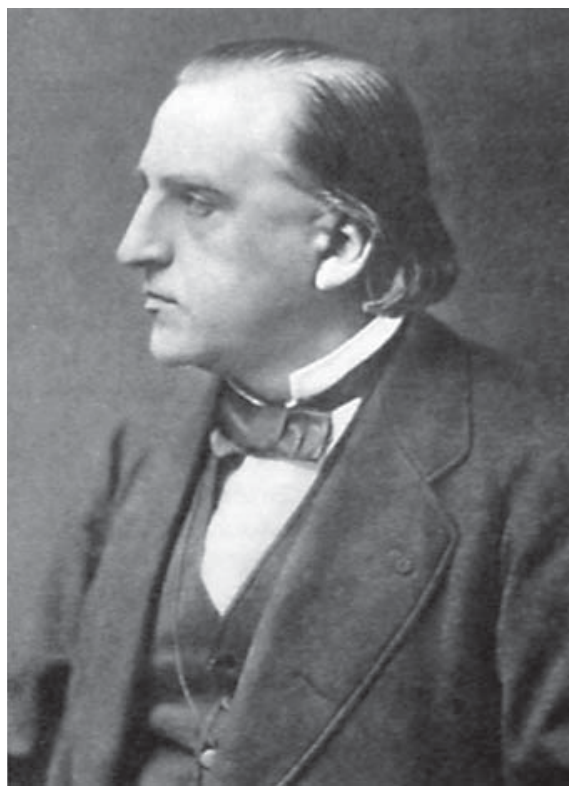

Fig. 1. Jean-Martin Charcot at the time of his early work as chief of service at La Salpêtrière in the 1860 s.
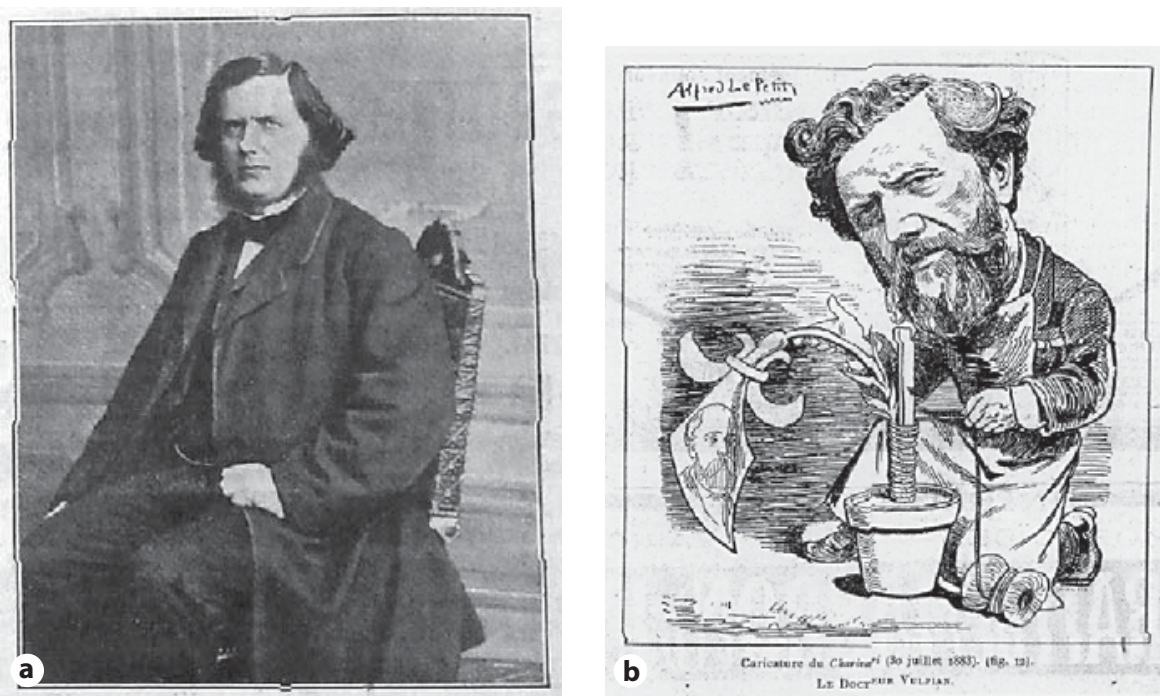

Fig. 2. Alfred Vulpian in 1864, 2 years after his arrival at La Salpêtrière (a) and 20 years later at the summit of his fame (b). Sketch by Jules Le Petit in the 'Charivari', showing Vulpian making a physiological experiment with a political result. was (Edmé Félix) Alfred Vulpian (1826-1887; fig. 2), who has been at times considered a neurologist and at other times a physiologist [3]. Charcot and Vulpian initially followed a close career during their training and when they arrived at La Salpêtrière both as chief of service in 1862 . Vulpian, however, moved on to other positions, while Charcot always remained 'faithful' to La Salpêtrière. In fact, Vulpian's career developed in a much more prestigious way than that of Charcot, who often seemed to follow his friend, once taking up his previous academic appointment, while Vulpian moved to higher honors and supported his friend's advancement.

However, the 31 years that Charcot continuously spent at the same place allowed him to build up a formidable group of collaborators, which became known as the 'Salpêtrière School'. Despite his excellence in scientific medicine and physiological research, as well as his great medical-political skills, Vulpian never had a similar 'school', and it appears that his memory has been partly erased by the space occupied by that of Charcot [4]. His memory even became overshadowed by the career of his own pupil Jules Déjerine (1849-1917), Charcot's second successor at La Salpêtrière, despite the active role of his wife Augusta Déjerine-Klumpke (1859-1927) during the centennial celebration of Vulpian's birth in 1927 [5]. This fate is exemplified by the fact that the recent Handbook of Clinical Neurology, which is devoted to the history of neurology, presented Charcot in a full chapter, while Vulpian did not even get a subchapter, receiving only a few lines in two places [6]. This article traces the parallels and divergences of Charcot's and Vulpian's careers, with the aim to underline a particularly successful friendship and collaboration (at first scientific, later to become mainly political) which shaped the early days of neurology.

\section{The Ideal Career}

Jean-Martin Charcot's career is well known [1], which is not the case for Alfred Vulpian, who was born on January 5, 1826, less than 2 months after Charcot (November 19, 1825). While Charcot came from humble beginnings in Paris, Vulpian's grandfather was a count, lawyer at the Paris parliament and General Inspector of the Domaine Royal. However, the family was impoverished by the Revolution and Vulpian's father died when his son was 3 years old - his early years were far from being easy. He failed to get accepted to École Normale (supérieure) and a carpenter apprenticeship was envisioned for him instead. However, in 1845 , he was lucky to get a job as aide 
préparateur (associate technician) at the Muséum d'Histoire Naturelle, where his skills were noticed by Pierre Flourens (1794-1867), who encouraged him to study medicine while giving natural history lessons as répétiteur at Collège Chaptal. Flourens became Vulpian's mentor, and from the beginning his influence and support helped forge the unique expertise which Vulpian developed in associating physiology with what would become known as neurology.

In 1848 , he was successful in receiving the same internat (residency) position as Charcot, along with Alexandre Axenfeld (1825-1876), Pierre Carl Potain (1825-1901) and Ulysse Trélat the younger (1828-1890), all of whom became great names in medicine. During his medical training, Vulpian remained closely linked to physiology, working in parallel with Flourens at the Muséum d'Histoire Naturelle, even replacing him for 3 years (18641867) for the teaching of comparative physiology [7-9].

Charcot and Vulpian were internes (residents) together at La Pitié, just beside La Salpêtrière, and they presented their doctoral theses just a few months apart in 1853: Charcot on gout, on March 16 [10], and Vulpian on the origin of cranial nerves, on July 21 [11]. In 1857, 1 year after Charcot, Vulpian was appointed médecin des hôpitaux, allowing him to practice independently in Parisian hospitals. The same year, Charcot was unsuccessful in gaining eligibility for a professorship (agrégation; Vulpian was not a candidate) [12] (fig. 3), but in 1860, along with Potain, both friends were successful (Vulpian at his first attempt) with closely related topics ('secondary pneumonias' for Vulpian, 'chronic pneumonia' for Charcot).

In late 1861, both Charcot and Vulpian were appointed chief of service at La Salpêtrière, where they started work at the beginning of 1862 . For over 5 years, the two young agrégés worked closely with each other, reorganizing their clinical services and grouping and classifying their patients into modern diagnostic categories. Before, most of the patients had just been staying in hospital with a label of 'insanity' [1].

This was the time when the scientific collaboration between Charcot and Vulpian was the most intense, leading to several presentations and publications, and the launch of a common pathological anatomy laboratory, where their work was not limited to the nervous system. This collaboration increased their scientific and political weight in the local medical world, which was still recognized more than 10 years later when a correspondent of the British Medical Journal called the couple 'twin brothers' or the 'Castor and Pollux of experimental physiology and pathology' [13]. Charcot had taken up the Cazalis

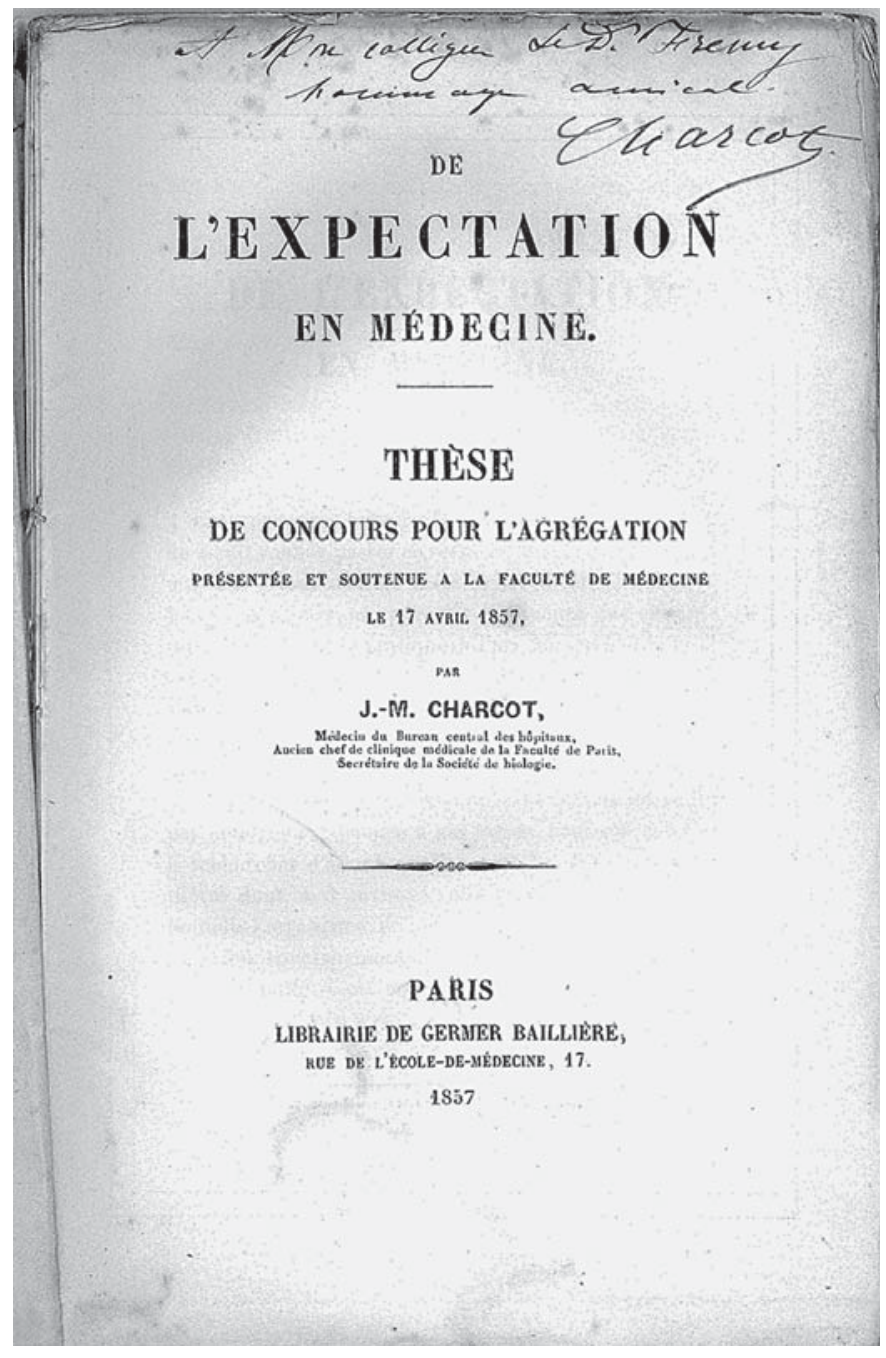

Fig. 3. Charcot's failed agrégation thesis in 1857 on 'expectation in medicine' (copy dedicated to Dr. Fremy).

service, which he kept for over 31 years until his death, while Vulpian, who was in charge of the Jacquart service, first moved to La Pitié in 1868, and then to La Charité and to Hôtel-Dieu, thus interrupting their close scientific collaboration, but not their friendship. During Charcot's time at the Cazalis service, Vulpian's successors at the Jacquart service included Jules Bernard Luys, Alix Joffroy and Fulgence Raymond, who was followed by Jules Déjerine after Raymond was elected to be the first successor to Charcot after a short interim by Édouard Brissaud [14].

This move was triggered by the fulgurant ascension of Vulpian, who in 1867 was appointed the successor to Jean Cruvheilier, the first holder of the chair of pathological anatomy since 1835. It is striking that when Vulpian left 
this position in 1872 to be appointed to the chair of experimental pathology, his successor was Charcot, who still had not been given a full professorship (he had failed in 1867 against Hardy and Axenfeld), with the strong support of Vulpian himself $[1,15]$. It is also interesting to note that Cruveilhier's chair was later again occupied by two famous neurologists, Pierre Marie (1908-1917) and Gustave Roussy (1925-1937). They came after Victor Cornil (1837-1908), one of the first of Charcot's residents, succeeded his master when the celebrated chair of Clinique des Maladies du Système Nerveux was created for him in 1882. The more rapid ascension of Vulpian was not linked to political issues, but to his scientific excellence, as shown by the fact that in 1866 his enormous CV contained 169 publications, around twice Charcot's number, making him the only credible candidate for the chair of pathological anatomy as recalled by Charcot himself after Vulpian's death [16].

In 1869, Vulpian was also elected to the Académie Nationale de Médecine, the highest medical body in France - despite oppositions from the clergy (like Charcot, Vulpian was a strong laicist). Also around this time Vulpian and Charcot, along with Brown-Séquard, founded the Archives de Physiologie Normale et Pathologique in 1868. Vulpian's progression into medical honors continued with his election as dean of the Faculty of Medicine in 1875, succeeding Adolphe Wurtz, and in 1876 with his election as a member of the most prestigious scientific corpus, the Académie des Sciences, of which he became secrétaire perpétuel in 1886. In contrast, Charcot was elected to the Académie de Médecine only in 1875, 6 years after Vulpian, and failed three times to enter the Académie des Sciences in 1878, 1882 and May 1883 (with only 1/57 votes!) [1] before finally being successful in November of the same year (with $46 / 58$ votes). When Vulpian died of pneumonia at 60 years of age in 1887, he was one of the most powerful and respected physicians in the country, holding the chair of experimental physiology and the prestigious Trousseau's service of medicine at Hôtel-Dieu, apart from his responsibilities at the Académie de Médecine and Académie des Sciences, and since 1880, the high council of public education (Conseil supérieur de l'instruction publique). He had been the main medical representative at the burials of Paul Broca and Claude Bernard, an honor which perfectly summarized his unique position encompassing both physiology and clinical neurology [4].

When the chair of Clinique des Maladies du Système Nerveux was launched for Charcot, who still had no full clinical professorship, Vulpian was dean of medicine, and his chairing of the faculty debates in May 1881 was in- strumental for getting a positive vote. Despite his apparent initial doubts associated with the fact that the minister had not consulted the professors, he managed to moderate the discussion to obtain nearly unanimous support. The discussion was indeed conceptual, because Charcot, who in 1875 had put forward the importance of specialization when he supported Benjamin Ball for the new chair of Clinique des Maladies Mentales et de l'Encéphale, now emphasized the importance of lumping together several topics under neurology which at the time were scattered among several medical fields [1].

Overall, Charcot's career was less rapid and brilliant than Vulpian's, and Charcot quickly found himself in the position to ask his friend for support in academic appointments. On the other hand, and contrary to Vulpian, Charcot focused his activity on building up a huge clinical service with a large number of collaborators and pupils [17], also including strong international activity [18], which became known as what we still call the 'Salpêtrière School'. Paradoxically, but as we may well understand it nowadays, this 'school' was much more effective in the diffusion and persistence of Charcot's memory, despite Vulpian's own excellence and life achievements or the efforts of the Déjerines to maintain his memory. This may explain how although Charcot clearly was in the shadow of Vulpian during a large part of his career, after his death, there was a progressive change of perspective associated with the persisting strength of Charcot's 'Salpêtrière School', which progressively shifted the scales and put Vulpian in the shadow of Charcot.

\section{The Neurological Disciples of Vulpian}

In neurology, Jules Déjerine was the main pupil of Vulpian. He never worked with Charcot, although in 1911 he became his second successor at La Salpêtrière, after Fulgence Raymond. While Déjerine was an important neurologist, clinically and scientifically, and clearly deserved the position, it is likely that his 1911 appointment against Pierre Marie was a reaction by a fraction of the medical faculty to limit the influence of the 'Charcot guys' [19]. However, this was not to last very long since Marie succeeded Déjerine at his death in 1917 and quickly chased his predecessor's collaborators out of La Salpêtrière, including Augusta Déjerine-Klumpke [20]. These episodes made people say that while Vulpian and Charcot always remained good friends, they fought each other through their pupils. 


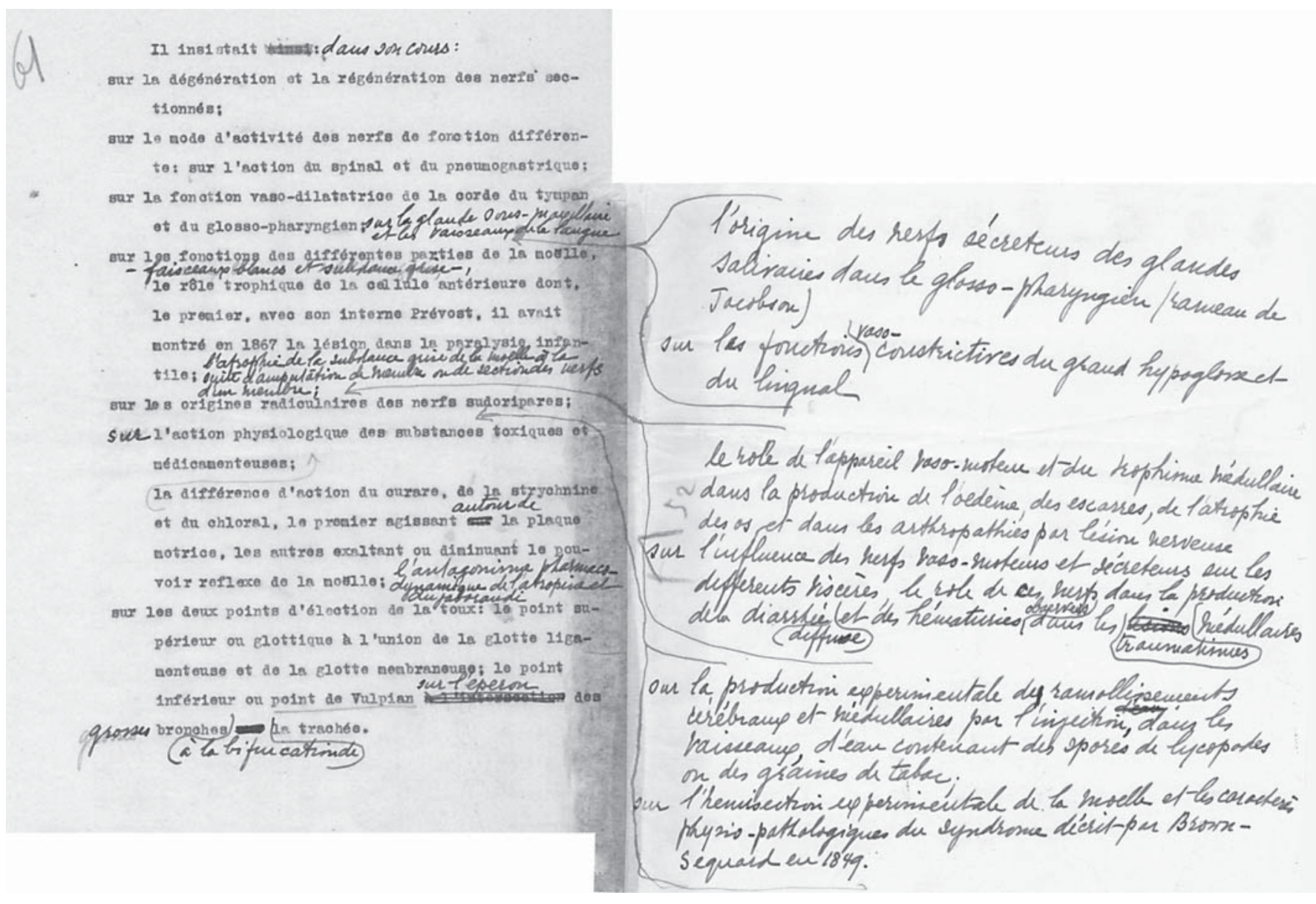

Fig. 4. Page of Augusta Déjerine-Klumpke's original corrected typescript of her speech at Vulpian's birth centennial celebration in 1927.

Déjerine was recommended to Vulpian in 1872 by JeanLouis Prévost and Georges Hayem, and started with him as externe at La Pitié in 1873. In letters and discussions, he underscored the availability and gentleness of Vulpian for his pupils, also emphasizing his style of careful clinical observation, along with his methodology and temperateness of conclusions [21]. During his internship, he worked in Vulpian's laboratory in the afternoons and published his first observations [22]. Later, Déjerine introduced Vulpian to his future wife Augusta Klumpke, whom he had met in Professor Hardy's service at La Charité in 1880. Vulpian probably would have been a best man at Déjerine's marriage if he had not died 1 year earlier in 1887 .

Augusta Déjerine-Klumpke also became a pupil of Vulpian, and with Babinski she was the leading neurological figure at the centennial celebration of his birth in 1927 (fig. 4), although she recognized that Vulpian, as faculty dean, had been opposed to allowing women - and herself in particular - to become interne (along with Blanche Edwards, they became the first women externe and interne in France) [23]. At the centennial celebration, she stated that with Charcot, Vulpian had been the founder of the Salpêtrière School, which was the cradle of French neurology [24]. It would have been more accurate to say, however, that along with Charcot, Vulpian had set up the bases which subsequently enabled his friend to build up that school.

While Déjerine always celebrated his mentor, he never spoke badly of Charcot. It is obvious that the two men respected each other, as emphasized in anecdotes reported by Gauckler [21], who reported that Charcot said Déjerine's character was stronger than that of any of his pupils. When in 1886 Déjerine applied to the agrégation contest among 21 candidates [25], Hardy was the committee chair, with Potain, Charcot and Bouchard among the jury. Apparently, Charcot had promised Vulpian he 


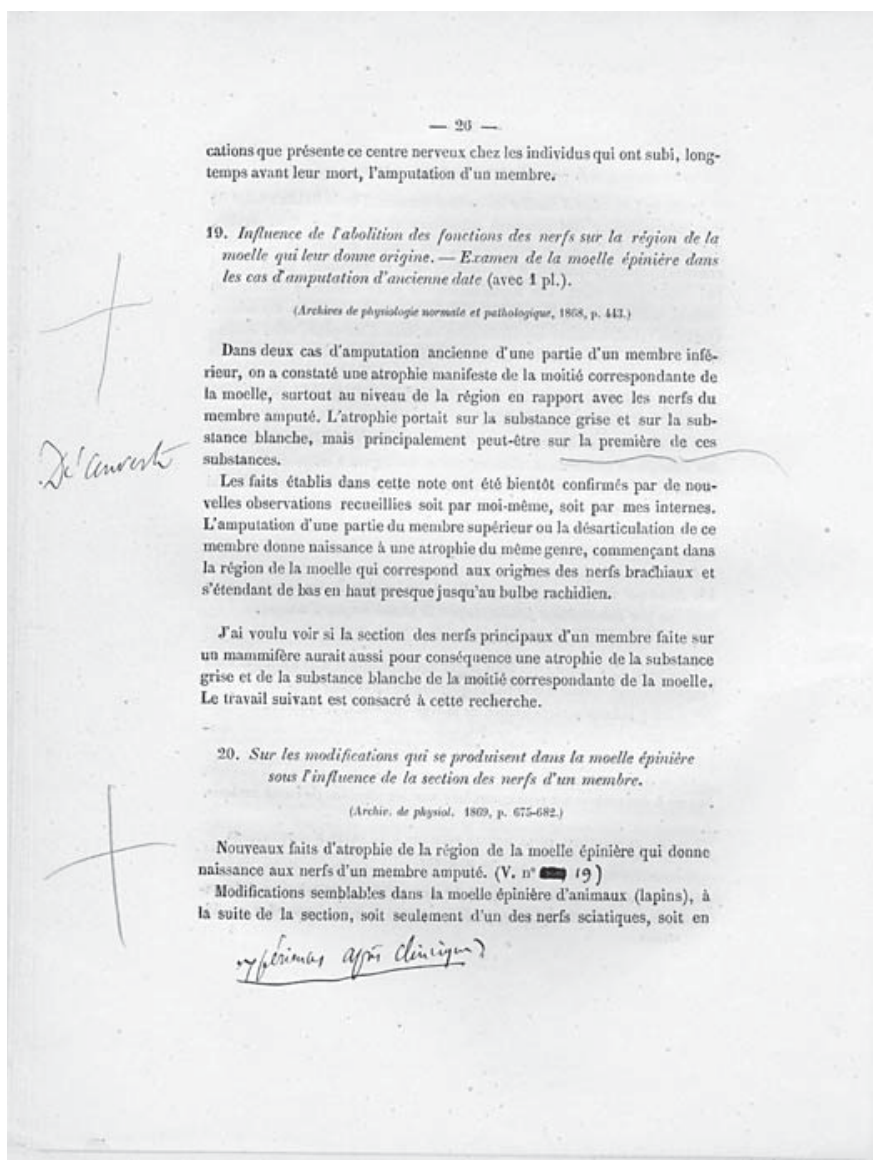

Fig. 5. Page of Vulpian's 1876 'Titles and papers' with corrections in his own handwriting.

would support Déjerine, and despite the fact that the meeting was rather agitated, and Hardy nearly resigned from the chair, Déjerine finally succeeded along with three other candidates, including two direct pupils of Charcot (Gilbert Ballet and Édouard Brissaud) [21].

Joseph Babinski (1857-1932), the most famous French neurologist in the 20th century along with Déjerine, is classically considered a pupil of Charcot but in fact never was his interne. On the other hand, during his internship, he worked with Vulpian on pathological anatomical projects [26] before being appointed the third chef de clinique (chief resident) by Charcot in 1885 [1885-1887], after Gilbert Ballet and Pierre Marie, but only because of the unexpected death of a colleague. With Charcot, Babinski followed mainly clinical projects, the most famous being on hysteria. Although he could have been a follower who would synthesize the experimental and clinical skills of Vulpian and Charcot, this did not happen, despite his
1885 doctorate thesis on the clinical-anatomical study of multiple sclerosis, a disease which had precisely been identified in 1865 by the common work of Vulpian and Charcot [27]. Interestingly enough, Babinski's most famous clinical contribution, i.e. the toe phenomenon [28], was not inspired by his years with Charcot, but by Vulpian who had already mentioned the extension of the great toe in paraplegics more than 20 years earlier [29]!

But in spite of this affiliation with the two greatest post-Charcot neurologists, Vulpian never really appeared as a cofounder of French neurology in equality with Charcot. The magnitude of his physiological work certainly was partly responsible for this, but it is likely that the subsequent stature of both Déjerine and Babinski also played a role in him being forgotten.

\section{The Scientific Collaboration between Vulpian and Charcot}

Vulpian is particularly well known for his 1866 report on the intermediate zone between nerve and muscle, which led to the discovery of synapses, and for his work on the function of the adrenal medulla, which would lead to the discovery of adrenaline $[3,4]$. He also introduced optic microscopy in anatomical-physiological studies to which he introduced Charcot during their La Salpêtrière early years [1]. Charcot and Vulpian both were strong supporters of the anatomical-clinical method, which was largely derived from Claude Bernard's experimental medicine, and in this perspective, Vulpian urged some caution in forming conclusions from single case studies too quickly [30].

It is well known that when they arrived at La Salpêtrière as chiefs of service in 1862, Charcot and Vulpian worked closely together, often making common rounds. All their common publications date from that period. It is interesting to have a look on how each of them summarized their collaboration several years later in their respective 'Titles and papers' compilations in 1876 for Vulpian [30] and in 1883 for Charcot [31] (fig. 5).

Multiple sclerosis is probably the main disease which is classically considered to have been identified and isolated due to the common work of Vulpian and Charcot. However, this may in fact be the worst example since there were no common publications on this condition, which both young agrégés worked on in parallel ('chacun de son côté' - each of us on his own side, as Vulpian wrote himself [30]) in the mid-1860s. In his initial presentation [32], Vulpian reported a spinal case, but he also used two cases of Charcot, and he repeatedly quoted Charcot's 
work on this disease in his 'Titles and papers' (No. 14, pp. 19-23) [30]. In contrast, Vulpian was quoted only once (for the reporting of the spinal form of multiple sclerosis) in Charcot's 'Titles and papers' subchapter on multiple sclerosis (No. 100-103, pp. 100-104) [31]. Charcot put more emphasis on the nosological features of the disease and how it became clinically differentiated from Parkinson's disease through careful studies of tremor, referring to his famous 1868-1870 lessons [1], while Vulpian referred to his 1865 paper in Union Médicale and mainly emphasized the pathological aspects, quoting works by Cruveilhier, Türck and Charcot, to whom he attributed the term 'plaque' (No. 14, pp. 19-23) [30].

In his 'Titles and papers' summary, Vulpian quoted 11 publications on 9 topics 'with Mr. Charcot' [30], including progressive locomotor ataxia (No. 5, p. 11; No. 7, p. 12; No. 10, p. 15), dural neomembranes in meningeal hemorrhage (No. 27, pp. 30-31), Parkinson's disease (called 'paralysie agitante'; No. 40, pp. 42-43), palatal muscles and nerves in diphtheric angina (No.47, pp. 47-48), blood and visceral crystals in leukemia (No. 65, p. 55), and ulcerous endocarditis (No. 55, p. 52) for their La Salpêtrière years, and two works from before that time, i.e. on stomach ulceration and dilatation with pyloric stenosis in 1854 (No. 77, p. 59) and brown pigmentation of the skin in lung tuberculosis with alterations of the surrenal capsules in 1857 (No. 52, p. 51). The work on locomotor ataxia (so named by Duchenne) or tabes dorsalis (so named by Türck and Romberg) at a time when the syphilitic origin was not recognized is a good example of the advances in the understanding of the pathophysiology of a neurological condition following the new clinical-anatomical correlation method developed by Vulpian and Charcot. They concluded that the 'irregularity of the movements of the limbs' was due to the involvement of the spinal posterior columns and posterior roots, which 'harmonize' the function of the grey matter in the spinal cord. Vulpian's and Charcot's common contribution on Parkinson's disease is also famous, but it is only shortly mentioned in both of their 'Titles and papers', especially from Charcot's side. He mainly underlined clinical features which had enabled them to distinguish that condition from multiple sclerosis [31], while Vulpian typically insisted more on physiology of tremor, including animal experiments [30]. While Charcot's responsibility for calling 'Parkinson's disease' a condition which was then called paralysie agitante is well known, James Parkinson was not quoted in his 'Titles and papers' [31], which is in contrast to Vulpian, who also mentioned previous contributions by French authors, e.g. Armand Trousseau and Germain Sée [30].
As compared to Vulpian, Charcot added a few more common contributions in his own summary [31]: miliary carcinosis (No. 14, p. 21), senile osteomalacia (No. 64, p. 63 ) and secondary degeneration of the spinal cord (No. 75, p. 71). He also presented observations reported in 1866 by Prévost and Cotard on gaze deviation in cerebral softening as being based on his and Vulpian's cases (No. 31, p. 178) [31], while Vulpian did not consider this work done together with Charcot (No. 36, pp. 37-39) [30]. Nowadays, the phenomenon is still often called 'Vulpian's law' [33].

Apart from his systematic, physiologically biased orientation, which was in contrast to Charcot's more clinically centered attitude, Vulpian also differed from his colleague in that he was considered an 'anti-localizationist' [34], probably not so much because he refused to correlate focal neurological dysfunction with anatomical locations, which he did, but because his scientific mind saw the developing danger of exaggerated localizationism, which at the time was emerging from single - and often poorly studied - cases.

\section{The Friendship 'for Life'}

Since their encounter as internes at La Pitié in the late 1840s, Vulpian and Charcot remained close friends, even when Vulpian left La Salpêtrière and La Pitié for La Charité when his career started advancing quicker and higher than Charcot's. Vulpian has indeed been said to have been Charcot's only friend of his generation, along with Guillaume Duchenne and Alphonse Daudet [1]. Apart from the usual dedications to family and previous mentors, Charcot dedicated his 1853 doctorate thesis 'to my friends Vulpian, Sévère, Forestier and Banaston' [10]. At Vulpian's funeral in 1887, Charcot stated that this friendship had been 'for life', and that despite unavoidable competitions, Vulpian's loyalty, generosity and 'chivalry' had been a constant feature of his personality [16]. Vulpian was best man along with Rayer, Charcot's mentor, and people outside the medical field at Charcot's marriage in 1864, while Vulpian's future wife, who was a friend of Charcot's wife, was introduced to him by Charcot in 1868. And on May 18, 1887, when Vulpian unexpectedly died at 60 years of age from pneumonia, two faithful friends who had shared a large part of their life since their common interne promotion on December 18, 1848 , were sitting at his bedside. These were Pierre Potain and Jean-Martin Charcot, which shows that no shadow, just light, had covered this lifelong friendship.

Eur Neurol 2011:65:215-222 


\section{References}

1 Bonduelle M, Gelfand T, Goetz CG: Charcot, un grand médecin dans le siècle. Paris, Michalon, 1997.

2 Bogousslavsky J, Moulin T: From alienism to the birth of modern psychiatry: a neurological story? Eur Neurol 2009;62:257-263.

3 Clarac F, Ternaux JP: Encyclopédie historique des neurosciences. Du neurone à l'émergence de la pensée. Bruxelles, De Boeck, 2008.

4 Fardeau M: Évocation du centenaire de la mort de Vulpian. Rev Neurol 1988;144:619620 .

5 Centenaire de Vulpian. Hyg Ment 1927;22: 40-41.

6 Finger M, Boller F, Tyler KL: History of neurology; in Aminoff MJ, Boller F, Swaab DS (eds): Handbook of Clinical Neurology, ser 3. Edinburgh, Elsevier, 2010, vol 95.

7 Déjerine J: Éloge du professeur Vulpian. Séance générale de la Société de Biologie du 22 décembre 1888. C R Hebd Soc Biol 1988, pp XXI-XXIV.

8 Camus J: Vulpian-chronique. Paris Méd 1913;12(suppl):733-747.

9 Laignel-Lavastine M: Vulpian (Edmé-Félix Alfred), 1827-1887. Bull Soc Fr Hist Méd 1927;21:287-303.

10 Charcot JM: Études pour servir à l'histoire de l'affection décrite sous les noms de goutte asthénique primitive, nodosités des jointures, rhumatisme articulaire chronique (forme primitive), etc; thèse pour le doctorat en medicine, Faculté de Médecine, Paris, 1853.

11 Vulpian EFA: Essai sur l'origine de plusieurs paires des nerfs crâniens $(3,4,5,6,7,8$, 9 et $10)$; thèse pour le doctorat en medicine, $\mathrm{Fa}-$ culté de Médecine, Paris, 1853.
12 Charcot JM: De l'expectation en médecine Thèse de concours pour l'agrégation présentée et soutenue à la Faculté de Médecine. Paris, Librairie de Germer Baillière, 1857.

13 Anonymous. The Salpêtrière. BMJ 1872;567.

14 Tatu L, Bogousslavsky J: The impossible succession of Charcot. The quest for a suitable heir. Eur Neurol, in press.

15 Guillain G: Jean-Martin Charcot, 18251893, sa vie, son œuvre. Paris, Masson and Cie, 1955.

16 Funérailles de Vulpian. Discours de MM. J. Bertrand, Charcot et Brown-Séquard. Paris, Institut de France (Académie des Sciences), 1887.

17 Walusinski O: Jean-Martin Charcot's house officers at La Salpêtrière hospital; in Bogousslavsky J (ed): Following Charcot: A Forgotten History of Neurology and Psychiatry. Basel, Karger, 2011, pp 9-35.

18 Goetz CG, Bonduelle M, Gelfand T: Charcot, constructing neurology. New York, OUP, 1995.

19 Paciaroni M, Bogousslavsky J: Jules Joseph Déjerine versus Pierre Marie; in Bogousslavsky J (ed): Following Charcot: A Forgotten History of Neurology and Psychiatry. Basel, Karger, 2011, pp 163-169.

20 Roch Lecours A: Aphasies: querelles. Centenaire de la Société Française de Neurologie. Rev Neurol 1999;155:833-847.

21 Gauckler E: Le professeur J. Déjerine, 1849 1917. Paris, Masson and Cie, 1922.

22 Déjerine J: Note sur l'existence de lésions des racines antérieures dans la paralysie diphtéritique. C R Soc Biol 1877, p 312.

23 Bogousslavsky J: The Swiss connection of Augusta Déjerine-Klumpke: from San Francisco to Lake Geneva and from Paris to the Thalgut. Schweiz Arch Neurol Psychiat 2011; 162:37-41.

24 Déjerine-Klumpke A: Discours présenté au centenaire de Vulpian, 1927 (tapuscrit/manuscrit original).
25 Déjerine J: L'hérédité dans les maladies du système nerveux; thèse présentée au concours pour l'agrégation (section de médecine et de médecine légale), Faculté de Médecine, Paris, 1886.

26 Philippon J, Poirier J: Joseph Babinski, a biography. Oxford, OUP, 2009.

27 Babinski J: Étude anatomique et clinique sur la sclérose en plaques. Paris, G Masson, 1885.

28 Babinski J: Sur le réflexe cutané plantaire dans certaines affections organiques du système nerveux central. C R Hebd Soc Biol 1896, pp 310-311.

29 Freeman W: Alfred Vulpian (1826-1887); in Haymaker W, Schiller F (eds): The Founders of Neurology. Springfield, Charles C Thomas, 1970 , pp $272-275$.

30 Vulpian A: Notice sur les travaux scientifiques. Paris, E Martinet, 1876.

31 Charcot JM: Exposé des titres scientifiques. Paris, Victor Goupy et Jourdan, 1883.

32 Vulpian A: Sur la sclérose en plaques de la moëlle épinière. Paris, Union Médicale, 1865 (summarized by the author in ref. 30, No. 14, pp 19-23).

33 Pearce JMS: Prévost's sign or Vulpian's law : conjugate deviation of the eyes; in Pearce JMS (ed): Fragments of Neurological History. London, Imperial College Press, 2003, pp 370-372.

34 Hécaen H, Lantéri-Laura G: Évolution des connaissances et des doctrines sur les localisations cérébrales. Bibliothèque de neuropsychiatrie de langue française. Paris, Desclée de Brouwer, 1977. 